\title{
Nurturing Jawi Through Education: Mirroring Jawi Education in Aceh and Malaysia
}

\section{Syukri Rizki ${ }^{1}$}

Southeast Asian Studies, Johann Wolfgang Goethe-Universität Frankfurt am Main, Germany

\section{Keywords}

Jawi; education; Aceh; Malaysia

\begin{abstract}
As Jawi - the Arabic orthography used to write Malay language - deals with more challenges in this sophisticated era, it requires more severe acts of nurturing its existence, one of which, education. Inferred to be originated from Aceh, the massive dissemination of Jawi got through the Malay Archipelago countries, including Malaysia, where it, compared to other countries, receives better treatment for its development nowadays. This paper seeks to trace the origin of Jawi and its development in the light of education in Aceh and Malaysia. The findings reveal that Jawi education in Malaysia has better developed with its outstanding features. Relevant journal articles, books, reports, and online pages are consulted to obtain the real picture of Jawi education in both countries. Positive innovations developed in Malaysian schools are expected to set a new benchmark for Jawi education in Aceh in particular and in other Indonesian provinces which are concerned over Jawi education like Riau, Islands of Riau, South Sumatera, North Sumatera, and Jambi.
\end{abstract}

\section{Introduction}

The education of Jawi - a term for Arabic script employed in writing Malay and Acehnese (Durie, 1996, p. 116) - in Aceh nowadays can be witnessed in formal schools after previously only took places in non-formal schools like Meunasaht ${ }^{2}$. Acehnese children normally begin to learn Jawi as they are first exposed to the education of how to perform prayers, recite The Qur'ān and execute other religious rituals. In this stage, as widely known, children are

\footnotetext{
${ }^{1}$ Corresponding email \syukririzki@gmail.com

2 Meunasah derived from an Arabic word 'madrasah' (school), it functions as a prayer, as well as religious discussion place.
}

educated by using several certain Jawi books like Masāil Al-Muhtady Bidāyah Al-Hidāyah, and Jam'u Al-Jawāmi' before they continue to the further education level dubbed Dayah whereby they will be taught using Arabicwritten books (commonly called Kitab Kuning) (Marzuki, 2011, p. 229; Jailani, 2017, p. 184).

In Aceh, however, Jawi ever endured some phases of declination, yet it survives until the present time. Of the factors which contribute to its decrease is the Japanese 
occupation of Indonesia, which lasted from 1942-1045, whereby Aceh students were restricted to learn Jawi instead of Katakana and Hiragana (Ibrahim et al., 1991, p. 187). The use of Jawi-written books remained firm until today in traditional religious schools (dayah) ("Dinamika Tulisan Arab-Jawi," 2014). In the dayahs, during the Jawi book learning, the method usually employed is what so-called Collective Learning Process whereby the teachers and the pupils open the same specific Jawi book; the teacher recites and elaborates while the students pay close attention and take important notes (Miszuwar, 2017, p. 16).

Since the onset of Jawi coincided with the coming of Islam (Moain, 1995 in Abdullah, Siraj, Hussin, \& Alias, 2010), the Indonesian Constitution No.44 year 1999, which mandated Aceh a privilege to implement Islamic sharia conjured the spirit of Islam again. This spirit then gave birth to some sharia rules, one of which, Qanun Aceh No.5 year 2008 on the implementation of education, article 35, verse 4 which calls for that "the curriculum of school/madrasah of every level ... may include muatan lokal (literally 'local substance' - extra subjects taught outside formal school hours) where necessary ${ }^{3}$. The local substance usually harbors Islamic Cultural History, Aceh History and Culture, Local Language, Arabic Malay, and other essential productive subjects, especially for vocational schools. Noticeably, this qanun prepared the ground for the Jawi to be taught and learned in schools (Srimulyani, 2013: 485). One of the local substances is Arabic Malay (Jawi). Previously, the actualization of Arabic Malay learning was manifested by including a subject called Tulisan Arab Indonesia (TAI) (Mahmazar, n.d.). In the capital of the province, Banda Aceh, motivated by the aspiration to shape a Madani civilized society, in 2011, the Jawi learning was integrated with Diniyah program which collects some religious subjects like The Prophet's Account (Riwayat Nabi), Tajweed, Akhlak, and Fiqh (Islamic

${ }^{3}$ Qanun constitutes a local sharia law produced in Aceh based on its capacity of possessing a special autonomy (Nazaruddin,
Jurisprudence) whose materials are mostly Jawi books. Unlike in traditional Aceh Islamic schools (Dayahs) where Jawi books are learned intensely, Jawi book teaching in formal schools suffered from limited time allocated, roughly 2 hours weekly. Also, problems like the slim participation of the students' parents, the absence of a curriculum, and insufficient facilities available are surely worth paying more severe attention (Adilandri, 2018). Suffice it to say that the call to use Jawi besides Rumi (Romanized Malay) and the inclusion of Jawi as one of the local substances supports the movements upholding Islamic shi'ar, which cannot be divorced from Aceh context.

In this regard, Aceh schools must internalize some other pedagogical innovations to nurture the existence of Jawi in Aceh, that is, in this case, by enabling the students to master Jawi. Besides helping the students cover a broader range of reading, Jawi mastery also has much to do with the urgency of retrieving the nostalgia of the past about the heydays of Jawi which evidently originated from Aceh. Alfian (1999) and Zain (2010) argued that Aceh's Hikayat Raja-Raja Pasai is believed to be the earliest manuscript written in Jawi. Since then, the dissemination of Jawi books produced in Aceh in the past did reach a broad area of Malay Archipelago.

Until now, we can find in the archipelago numerous educational institutions that are still highly concerned over the development of Jawi. One of the countries which care about Jawi is Malaysia. Its innovations in education are relatively exemplary that other schools in Indonesian provinces that work to boost Jawi education like Aceh may copy. Accordingly, this paper seeks to figure out some noticeable features of Jawi education in Malaysia and Aceh schools. Relevant positive innovations developed in Malaysian schools are expected to set a better benchmark for Jawi education in Aceh in particular and in other Indonesian provinces, which are concerned, too, over Jawi

Safa’at, Fadli, \& Nurjaya, 2016). 
like Riau, South Sumatera, North Sumatera, Islands of Riau and Jambi.

Based on the explanation sketched above, the objective of this study is to compare two variables. One is the instructional practice in Aceh school and other is the instructional practice in Malaysian schools so as to address salient issues namely, ownership of the school, structure of the school, the curriculum, teachers' qualification, teaching methods, evaluation procedure, teachers' welfare, and socio-economic status of the teachers. The significance of this paper is to expose the strengths and deficiencies of Jawi instruction in Aceh and Malaysia. Aceh is surmised to have less improvement while Malaysia is expected to be a role-model for Aceh for now and for the future after the promulgation of the two aforementioned qanuns. Accordingly, the current paper firstly provides a historical background of the onset of Jawi in Aceh, followed by the information about the Jawi education actual condition in Aceh and Malaysia gathered from some articles and books, either the online or offline ones, and my knowledge. By doing so, content analysis can be performed to identify essential features that define today's Jawi education in Aceh and Malaysia, as well as the challenges it encounters. Next, plausible reasoning is conducted to discover which relevant innovations of Jawi education instruction should be maintained, diversified, and developed. Ultimately, the conclusion and suggestion parts will cordially close the paper.

\section{Condition of Current Jawi Education in Aceh}

Some previous researches on Jawi education are consulted to figure out the Jawi growth in Aceh. A study by Marzuki (2016) entitled Diniyyah in Public Schools: A Model of Islamic Curriculum Implementation in Multi-Religious Society in Banda Aceh-Indonesia found that

${ }^{4}$ Diniyyah program is an extracurricular program with extra religious subjects taught normally in the afternoon. The program was previously targeting only primary school students, not it is
Diniyyah program can run effectively and does not displease the non-muslims. Hardly does the program undermine the existing Indonesian national curriculum since it is administered in the afternoon post the formal school hours. The second research was performed by Eka Srimulyani (2013) under the title of Islamic Schooling in Aceh: Change, Reform, and Local Context. She discovered the reaction of Aceh Islamic schooling towards social-political change, local autonomy policy, and formalization of sharia law. However, the two studies do not narrow the discussion specifically on Jawi education, but instead generally on Islamic education in Aceh.

Another research was entitled 'Implementasi Metode Pembelajaran Teks Jawi Kitab Kuning di Dayah Latansa Zikrullah Mugan Kecamatan Montasik by Miszuwar (2017). This research found information about the methods used, the students' preference of the plans, the students' feelings towards the Jawi book learning, learning hours, students' responses to their ability in understanding Jawi text, titles of Jawi books used, and examination conducted. However, this study was performed in a dayah environment where Jawi books are already learned very intensely.

Indeed, hardly can we find researchers in Aceh who correctly orient on studying the current condition of Jawi in formal education. In this respect, it is indispensable to re-think the status of Jawi in Aceh from its heydays until how Acehnese people treat it nowadays in the education sector.

\section{Research Methodology}

Relevant to the problem mentioned above and the study's aim, this study employs a specific methodology. In terms of approach, this study uses a qualitative which is attributed to some standard features (Sherman \& Webb, 2005). First, it should be a context-specific as opposed to researchers in, for example, physical sciences

also served for junior and senior high schools students (Novita, 2019). 
which do not depend upon any contexts. Second, although it may entail academic settings, it should be performed in a natural environment. Third, it deals with the wholeness of the experience studies, meaning that experience is being studied by involving its past and its present times. Fourth, it interprets the experience considered and figures out its significance. On this wise, the present study specifies the subject which is Jawi in education in Aceh and Malaysian formal schools, naturally set, considers the past and the present conditions of the Jawi education closely, and searches for the significance of Jawi education.

Content analysis is employed to analyze the data. A content analysis is, as demonstrated by Neuendorf (2002, p. 10), is "a summarizing, quantitative analysis of messages that relies on the scientific method (including attention to objectivity-intersubjectivity, a priori design, reliability, validity, generalizability, replicability, and hypothesis testing) and is not limited as to the types of variables that may be measured and the context in which the messages are created and presented." In this study, all reachable relevant secondary data such as journal articles, related books, online websites, conference papers, Youtube videos, and blogs are analyzed.

\section{Historical Background}

As the center of the Malay World by the $18^{\text {th }}$ century (Andaya, 2001, p. 30), Aceh, if traced, is regarded as the land where the Jawi was firstly discovered in a written script. Aside from the indisputable, exact date of the two widely recognized most earliest texts, Aqā ìd AnNasafy (dated back to1950) and Täjussalātin (dated back to 1603) (Ariffin, 1999, p. 223), Aceh's Hikayat Raja-Raja Pasai possesses some

\footnotetext{
${ }^{5}$ The ancient words are like anakda for 'anakanda', and tuha for 'tua'. Further, the hikayat also contains the Sankrti-originated words nugeraha, anugraha, dianugrahai for the current 'anugerah'; whereas Tajussalatin simply only mentions 'anugerah'. ${ }^{6}$ Like Hikayat Aceh by Syamsuddin As-Sumatrany (Andaya, 2001, p. 47).

${ }^{7}$ Like Bustānussa爪̃ tin by Nuruddin Ar-Raniry and Tājussalātin by Buchari Al-Jauhary (Harun, 2017, p. 7).
}

evidence to emphasize that it had existed earlier before the two scripts were written (Zain, 2010, p. 1). The hikayat mentions some considerably old words which then more strongly stress its existence before the $17^{\text {th }}$ century. ${ }^{5}$ Later on, a wealth of other Malay scripts discovered, ranging from literary works, ${ }^{6}$ constitution, ${ }^{7}$ trading letters, ${ }^{8}$ religious texts ${ }^{9}$ are evident to origin from Aceh.

Aceh was in the $16^{\text {th }}$ and $17^{\text {th }}$ centuries perceived as the center of Malay World civilization, which took Islam as its defining feature (Andaya, 2001, p. 38-39). Of the cardinal aspects of the Malay World civilization is Malay language usage as a lingua franca, which is based on Islam (Abd Jalal et al., 2018, p. 155-158). For the Malay World, the period from the $14^{\text {th }}$ $17^{\text {th }}$ centuries was deemed as the Islam heydays during which Jawi books were produced (ibid.). Since then, Jawi books became a salient medium to spread Islam (ibid.).

In Aceh alone emerged several of phenomenal works as a contribution to the Malay civilization. Of the examples are Nuruddin Ar-Raniry, whose work 'Sirātal Mustaqim', which was edited in Banjarmasin by Sheikh Arshad Al-Banjary; and Abdul Rauf AsSingkily whose work was studied in Sulawesi, Button, Mindanao, and Pattani (ibid., p. 162). Other Aceh scholars' works were and are still used across the Malay World (ibid.).

Even so, there still different views commenting on when and in which part of Malay Archipelago Jawi firstly existed. But, one for sure, Jawi has been widely recognized and used in the Malay World civilization since it served as a bridge language commencing from the $14^{\text {th }}$ century to the mid-20 $0^{\text {th }}$ century (Aziz, Wan Sulung, \& Alias, 2017, p. 188). Since then, Jawi thrived and enjoyed various concerns over its writing reformations. It is noted that Jawi

\footnotetext{
${ }^{8}$ Of the oldest letters is a trading permission letter dated to 1603 dispatched by Sultan Iskandar Muda to King James I of England. ${ }^{9}$ Sirāt Al-Mustaqim by Nuruddin Ar-Rāniry (Shiah, 2005), Mir'atul Mu'min by Syamsuddin As-Sumatrany (Andaya, 2001, p. 46-50), and Mir'atut Thullab by Abdurrauf As-Singkily (Harun, 2013, p. 120 ) are among those written $\ln 15^{\text {th }}$ and $16^{\text {th }}$ century.
} 
experienced several acts of nurturing its writing system to fit the development of the Malay language lexicon. ${ }^{10}$

In Aceh, throughout its historical literature, Jawi repeatedly receives mentions as Malay, Arabic Malay, Malay Jawi, and Basa Jawoe (Durie, 1996, p. 115). In this light, there are two common understandings of what Jawi is. Raseuni Khan (in Voorhoeve and Iskandar, 1994, p. 349) - motivated by the alleged preeminence of Malay literacy whereby only a few Acehnese people can understand the language - initiated the translation of Akhbār Al-Äkhirah into Acehnese language; this implies that he perceived, so did Van Der Putten and Cody (2009, p. 139), that Jawi is merely the Malay written in Arabic. In the same vein, Le Roux (1998, p. 234) also notes that Jawi is an old way Malays write their language using Arabic characters. A broader definition is demonstrated by Durie (1996, p. 116) who contends that Jawi is attributed to an orthography used in writing both Malay and Acehnese; this seems to be a somewhat preferable definition since the Acehnese themselves refer the writings in the two languages using Arabic script as Jawi. Henceforth, in this study, the terms Jawi and Arabic Malay are interchangeably used since they suggest the same entity.

\section{Jawi in Education}

The use of Jawi is considered as an act to nurture the sustainability of the writing itself. At present, as a matter of fact, in Aceh, the positive impacts of the implementation of the two qanuns can be noticed. Regarding the qanun 2002, positive supports from Acehnese people are shown because in all Aceh regencies, Jawi is seen on many signboards of governmental offices, private institutions, schools, stores, hotels, and hospitals. Meanwhile, concerning the qanun 2008,

${ }^{10}$ For example, Za'aba (1949 and 1965), Matlob (1989), Pedoman Ejaan Jawi yang Disempurnakan (PEJYD) (1986/93), Mohd Hussein (2002), Daftar Kata Bahasa Melayu (2005-DKBM 1/ Second Edition 2008 - DKBM2), Che Siah (2006), Adi Yasram and Hasim Musa schools did include Jawi subject as an extra lesson, which is also tested in the examination. Jawi preservation is mainly manifested in education sectors whereby the students learn Jawi to understand Islamic teachings contained in some classic religious books, e.g. Masā îl AlMuhtady Li Ikhwān Al-Mubtady, Jam'u Jawāmi' Al-Mushannafät, and Perukunan Melayu Besar: In this light, based on my knowledge and the secondary sources I studied, this paper reveals the features which define the strengths, deficiencies, as well as challenges faced by Jawi education development in Aceh and Malaysia, which are highly worth elucidating.

\section{Features}

\section{A Law-based program}

Both Aceh and Malaysia include Jawi as a subject based on the legal law of each. For Aceh, the recommendation to use Jawi letters was firstly issued in Qanun 2002, and then its implementation is supported by Qanun 2008. No. 5 the year 2008, on the implementation of education, article 35 , verse 4 . Implementation based on Qanun in Aceh context is valid and can be continued because a qanun's strength equals to constitutional law or Undang-Undang (Sapardjaja, 2012, March 7). On the one hand, some Qanuns on Islamic Sharia are contested by human right groups and suffer from negative framing on national and international media (Sukoyo, 2015, October 23; Afif, 2014, October 3). But, on the other hand, the implementation of the Qanun 2002 in the unit of Islamic Education particularly in the inclusion of Muatan Lokal has hitherto received no contest since the nature of the Muatan Lokal itself is something needed by natural, cultural, and societal environment as well as by the respective regions (Nasir, 2013, p. 03). Additionally, the Jawi class takes place outside school hours, generally in the afternoon, after the obligatory classes finish (ibid. p. 15).

(2008), Hamdan (2014) and Azman (2014). As the latest came Pedoman Umum Ejaan Jawi Bahasa Melayu (PUEJBM) which is included in the DKBM (Aziz, Wan Sulung, \& Alias, 2017: 188). 
In Malaysia, after the launching of Akta Bahasa Kebangsaan," the use of Jawi among Malays drastically inclined. Responding to this, in 1985, Jawi was included as one subject in Islamic education promulgated by the Ministry of Education Malaysia (Rahim \& Hamzah, 2016, p. 55; Yusoff, 2005, p. 25). Still, on that occasion, Jawi subject exclusively targeted the students from the third year onward. Then in 1990, considering the dissatisfaction with the passage of the policy, Jawi subject was served for students beginning from year one. As yet, Jawi topic is included in the so-called J-QAF (Jawi, AlQur'ān, Fardu Ain) program, released in 2005. More intriguing is that this program has also developed by designing a particular curriculum for students with special needs (Ujang \& Salleh, 2018, p. 59). However, integrating Jawi into JQAF suggests that Jawi is merely learned in the area of Islamic education subjects, not as a subject whereby the students learn how to write Malay in the script, let alone the status of the subject which is not obligatory, hence the low students' interest in it (Jasmi, 2010, p. 13).

In this regard, a new policy has just been released lately by the Ministry of Education Malaysia through which it plans to include Jawi and khat learning in Malay Language subject. The ministry argued that Jawi and Malay language necessarily should not be divorced since the former is the original form of the later's writing system. Hence, despite the pros and cons of the policy, it is very likely that including Jawi in Malay Language subject can arguably collect more numbers of students since Malay Language subject is served for all students, regardless of their ethnicity and religious background.

\section{Jawi vis-à-vis Qur'ānic Letters}

As commonly recognized, Jawi letters consist of 28 Arabic/ Qur'ānic letters plus some additional letters. In Aceh, the children taught

${ }^{11}$ Akta Bahasa Kebangsaan, or National Language Acts is Malaysian law which consolidates the law, consisting of 11 sections, relating to the use of national language. In the section 'Script of national to spell Qur'ānic letters roughly at the age of 6. There are some methods like Baghdā diyyah and Iqra' by which the students learn how to spell letter by letter, further word by word, then phrase by phrase and ultimately recite quotes from The Qur'ān. After succeeding this stage, they would be served with some additional subjects whose learning materials are Jawiwritten books. In this light, considering the similarity possessed by Arabic and Jawi letters, learning Islamic subjects using Jawi books prepares the ground for the Malay Islamic academic culture to be nurtured (Rusdi, 2016, p. 03). Thus, learning The Qur'ān integrated with learning Jawi-written books can be a mutualistic process that enables the student to have a good familiarity with Qur'ānic verses they should fluently read in the further schooling levels (ibid., p. 21).

Similarly, in Malaysia, the earlier mentioned J-QAF program is of the utmost importance concerning Islamic education. Directly speaking, as the students learn and master Jawi letters, automatically they also master the letters of The Qur'ān, hence the merely short time needed to allocate to teach the students The Qur'ān. But, this does not suggest that the Qur'ān subject should be integrated with Jawi since it requires additional rules of correct recitation. Ahmad, Othman, Afkari, Rusdi, and Rahim (2012) supported this 'short-cut' concept on the one hand, yet on the other hand, they argued it by pointing out that the different ways of Qur'ānic letter learning, letter spelling methods, in particular, are plausibly a hindrance when juxtaposed with Jawi letter learning.

\section{Curriculum}

A curriculum plays a notable role in education since it allows the teachers to determine the strategies to employ when assessing students' progress (Phatankar, \& Jadhav, 2013). Without 
a curriculum, the teachers can hardly be sure whether or not they have transferred sufficient knowledge to their students (ibid.). Indeed, a curriculum is not invariably supposed to depend upon national education policymakers because the curriculum is all the learning which planned and guided by the school, whether it is carried on in groups or individually, inside or outside the school' (Kelly, 1983, p. 10).

In Aceh, although Indonesian schools have subscribed to the policy of following the national curriculum, the Diniyah program is not implemented nationally and thus suffers from the absence of particular curriculum (Adilandri, 2018); that is why it is imperative to accelerate the decentralization of establishing curriculum process, meaning that the teachers of Jawi subject can autonomously contribute to designing a specialized curriculum.

On top of that, translating a curriculum into action inevitably entails good teacher training. Again, to organize training does not necessarily depend always on the department that launches the curriculum. In reality, we can witness that to boost the teaching practice in classrooms, both novice and professional teachers need continuous teaching training, which can be provided by various agencies, e.g. university, school, or independent institutions (Boudersa, 2016). To this end, the institutions in Aceh that are concerned over, or mainly responsible for, such training are like Regional Office of Ministry of Religious Affairs Aceh Province which has Diniyah and Pondok Pesantren Division since one of the division's missions is 'to improve the quality of teachers and education personnel of Qur'ān Learning Center (TPA), Diniyah Takmiliyah, and Religious School (Ponpes)' (Kanwil Kemenag Aceh, n.d.).

Besides, other institutions which identified to ever held such a training for diniyah teachers are like Department of Education, Youth and Sports (Dispora), State Institute for Islamic Studies Cot Kala Langsa and Komite Penguatan Akidah dan Pengamalan
Agama Islam (Kemenag Aceh, 2012 July 07; IAIN Cot Kala Langsa, 2012, October 15).

In Malaysia, to date, Jawi subject complies with the curriculum for Islamic Education called Kurikulum Standard Sekolah Rendah (Standard Curriculum for Primary Schools). One of the objectives of the curriculum stipulates that students should be able to write and read Jawi and love it as the legacy of the state'. Through the curriculum, the students armed with the ability to master pronunciation and master the reading and writing of Jawi letter, syllable, word, and text so that they can read, create, and write sentences or paragraph in Jawi script themselves. Additionally, the Ministry of Education Malaysia introduces the Excellent Jawi Camp program, which has three objectives, namely, to recognize, read, and write Jawi, either separately or in a connected form, to read and write open and closed syllables; and to read and write short sentences. Additionally, a dictionary called Kamus Bergambar J-QAF KSSR is also produced to support the instructional process

Concisely, as opposed to Aceh, Malaysia currently seems to be more attentive to Jawi subject. The curriculum provides a reasonably detailed syllabus containing a guideline to teach Jawi.

\section{Instructional Material}

In Aceh, as Qur'ānic letters are introduced to the students at the very beginning level of formal school, Jawi subject follows consecutively. Individual Jawi letter recognition comes first before the students learn to read the letters in a connected form. In this stage, the materials used are guideline books like Bintang Lima: Buku Bacaan Aksara Arab Vol. 1 and 2, written by Usman Sulaiman (n.d.). As they can read and write phrases and short sentences, the teachers usually would serve them with higher learning materials such as Jawi-written books on fiqh, tajweed, or tauhid. In this level, the students are perceived to be able to read and understand the content while 
Jawi acts as the medium of other science delivery.

Interestingly, compared to Rumiwritten books, Jawi books are preferred due to the practicality in reading it. Commonly, when it comes to referring to Islamic sources, most people refer to secondary sources, the books unraveling the content of the Qur'ān and Sunnah. Due to the complexity of Arabicwritten books, Jawi-written books preferred to refer to (Ali \& Kamaruddin, 2009, p. 07).

In Malaysia, as described earlier, the curriculum on Islamic education has prepared the whole package, including teaching materials. Therefore, the teachers only need to deliver the teaching with an attractive teaching method to make the students engaged and arrive at the objective of education. Citing an example, the Excellent Jawi Camp program mentioned above provides a guideline handbook which - besides determining the elements of mastery - comprehensively contains writing materials, oral competence drill materials, and reading materials (Ministry of Education Malaysia, n.d.).

\section{Teaching Method}

In Aceh, Samad (2018, p. 508), in her study entitled "Pembelajaran Arab Melayu dan Pengaruhnya terhadap Pembentukan Karakter Siswa di Sekolah Dasar Kabupaten Pidie Aceh," noted that commonly there are two methods used in giving Jawi class, halaqah and peerteaching. The former is a model whereby the students sit around a teacher, opening the same Jawi book. As the teacher is reciting and explaining, the students listen and take important notes. The later is a model whereby one student, considering his sufficient capacity, is trusted by the teacher to teach his fellows.

On top of that, Miszuar (2017, p. 16-25) points out five more models. The first one is Sorongang (Individual Learning Process) where each student receives chance to have face-toface instruction. Second, the students should engage in a discussion forum called Musyawarah. Third, the students are given, for example, a specific problem and are supposed to solve it, this is called Bahtsul Masa'il. The fourth model is called Pengajian Pasaran where students should attend a sequence of classes given during a certain period of time such as a routine class during Ramadhan month. The last one is Muhafazah where students under a teacher's supervison memorize Quranic verses, important excerpts from Islamic books, and Arabic grammar formulas.

We can infer that in this case, the teachers are still employing conservative, tedious, and not exciting mode such as giving a lecture, classical, and bare explanation; and the very slim use of a student-center approach

In Malaysia, owing to the dwindling interest of students learning Jawi, Malaysian governments are working to figure out better strategies to address the problem. Malaysian education activists have introduced some innovations that have boosted the students' avidity in learning Jawi. Shitiq and Mahmud (2010) pointed out that by submitting a multimedia edutainment game, Ladder and Snake, the students got their interest Jawi escalated. This was so because the game is actually a very familiar traditional game among Malaysian children. The game is then automated so that it can be able to play on the computer.

For kindergarten students to recognize Jawi letters, Rahim and Hamzah (2016) pointed out that E-Jawi: Digital Learning Tool for Jawi Character Recognition has successfully attracted early age children to learn writing in Jawi, thanks to the practical technique the project offers, i.e. the use of grid baselines which involves the movement of hand and fingers.

More impressive is that the students with 'special needs' are now guided to learn Jawi through the inclusion of the so-called Jawi Braille. Besides being employed to teach regular students, Jawi Braille also works for visually impaired students. One for sure, the teachers themselves should have excellent competence in using the Braille machine before executing 
the teaching-learning activities. Majid (2017, p. 61) found that the usual methods used to teach regular students, e.g. dictation, listening and speaking, drills, memorization, and giving lecture, can also apply to the students with special needs.

On the whole, compared to Aceh, Malaysian Jawi education has developed better as it is now working to diversify the teaching method used in serving Jawi class.

\section{Teacher Qualification}

In Aceh, there is no certain degree in universities only to prepare the teacher candidates to teach Jawi. In the field, whoever possesses the capability to read Jawi books and execute teaching seems to satisfy the requirement of becoming a Jawi teacher. The implementation of Diniyyah program, for instance, opens more opportunities for those having good Jawi command - regardless of their formal university qualification whether or not in education field - to teach Jawi after being tested their ability in reciting and writing Qur'ān, reading classic Islamic books (Kitab Kuning); and their Islam knowledge (Fikri, n.d, p. 14; Kemenag Aceh, 2012, July 07). Moreover, the formal schools may cooperate with, or usually recruit, teacher of dayahs where Jawi books are commonly used as Islamic references (ibid.; Pemerintah Aceh, 2013, October 02).

However, due to the lack of Jawi teachers' capacity, or their performance in giving class, teacher training is mostly required. A training, in the education context, is attributed to preparation by which the teacher is prepared before receive a new assignment or shouldering a responsibility (Richard \& Farrell, 2005, p. 03, as cited in Boudersa, 2016). To do so, it entails, for instance, workshops through which the teacher may get themselves up-todate in their subject area (ibid.). Poor training, let alone an absence of it, may potentially cause the teachers to have slim command on their subjects, jejune pedagogical skills to teach, and serve the students with appropriate learning experience (ibid.). In Aceh, hardly can we hear about training for Jawi book teachers, although there are some held for Diniyah teachers in general (Dikbud Banda Aceh, 2017, October 24; Kemenag Aceh, 2017, May 18)). Shortly, poorly equipped Jawi teachers will hamper the students to obtain meaningful learning.

In Malaysia, although numerous studies are concluding that Jawi instruction needs revamping and diversifying, to some degree, it is better than that of Aceh. Researching 309 Jawi teachers in Selangor, Suhid, A., Che Noh, M. A., \& Abdul Mutalib, $\mathrm{L}$ (2014) found that all of the teachers are qualified with a bachelor degree and more than half of them hold a diploma in education certificate. The majority of the teachers have at least one-year teaching experience (ibid.). As far as this concerned, the Ministry of Education invariably ensures that the minimum standard of Jawi teachers is holding a diploma in education with a specialization in Islamic knowledge (Mamat, Kamis, \& Rashid, 2012).

Likewise, Nahar, Safar, Hehsan, and Junaidi, J (2017) randomly selected 217 Jawi teachers in urban and rural schools in Malacca; one of the objectives is to figure out their level of professional competency. The researchers categorized the qualification into academic qualification and professional qualification. It is found that the majority of the teachers are undergraduates and an only a small number of them who are non-graduates. In terms of professional skill, teachers with a diploma of education counted for the highest number, followed by those holding bachelor of education and those holding certificates of education.

Put succinctly, both in Aceh and Malaysia, and a suitable qualification profoundly matters when recruiting Jawi teachers, although the ways of determining the eligibility go through a different procedures.

\section{Challenges}

As explained above, Jawi has rooted for quite a long time in Aceh and Malaysia. However, 
nurturing Jawi through education inevitably should cope with two significant challenges.

\section{Romanized (Rumi) Letters' Domination}

Owing to the European colonization, be it of the British or the Dutch, in the Malay Land, Rumi letters came and dominated the Jawi (Ahmad, Othman, Afkari, Rusdi, \& Rahim, 2012, p. 85). In Aceh, Rumi letters make a severe rival to Jawi over the period. Alfian (2004, p. 197) noted that the Dutch colonizers were those responsible for the demise of Jawi in Aceh. The opening of a school initiated by Van Daalen - a civic and military-appointed on 14 September 1904 - in 1907 marked the onset of Romanized letters' development in Aceh. Further, he mentioned that Rumi letters literacy merely counted for $1,1 \%$ in 1930, suggesting the extensive use of Jawi and the gradual rise of Rumi letters. The serious decline of Jawi was noticed during the New Order in which the number of formal schools in Aceh soared, suggesting the people's leaving the madrasahs where Jawi was taught (ibid.).

Nowadays, noticeably, the acute Jawi illiteracy can be witnessed through the actual condition that learning materials that are circulating in schools written in Romanized letters, including Islamic books, which were previously preferred to be written in Jawi. The easiness of reading and publishing Rumiwritten texts gets most Acehnese people lessaccustomed to read Jawi

In the context of Malaysia, the language Congress in Singapore in 1956 did encourage the use of Rumi besides Jawi, not to mention the establishment of Dewan Bahasa dan Pustaka which intensify the spread of Rumi through its publications (Mahmazar, n.d.). Consequently, the policy had brought about the people's unfamiliarity towards Jawi, although in 1985, the Ministry of Education Malaysia realized the importance of Jawi as a legacy and obligated the inclusion of Jawi writing subject in elementary schools (Yusoff, 2005, p. 25).
On balance, Aceh and Malaysia share the same fact that Rumi letters denote a rival, if not a threat, for the widespread use of Jawi. Thus, it is necessary to continuously promote Jawi learning to preserve its usage in Aceh. Otherwise, a long absence of acute care will bring about the discard of Jawi, like what happened to the Turkish Arabic alphabets during the regime of Mustafa Kemal Ataturk (Mahmazar, n.d.).

\section{The Discontent of Some People}

The Malaysian government has recently announced that for the Malay language syllabus Jawi with the addition of Arabic calligraphy lesson (khat) should be included to be taught for Year Four students (Ar, 2019). However, this policy sparked uproar and displeasure among those who do not identify themselves as Malay or Muslims. Islamization is surmised to be the alleged cause that may jeopardize nonmuslims' faith. An example for this is The Malaysian Consultative Council of Buddhism, Christianity, Hinduism, Sikhism, and Taoism's dissent over the policy, although it promoted Jawi as a part of Malaysia's identity (FTM Reporters, 2019). In this light, the argument raised is that Malaysians unified with the Malay language, not Jawi or khat, which are associated with the attributes of Islam.

As this case has much to do with religious and ethnic issues, Malaysian vernacular schools are the education institutions that are seriously vexed by the policy. Even so, for these schools the Jawi subject basically can only be taught if it reaches the consent of the majority of parents or parent-teacher association (PTA) (FMT Reporters, 2020, January 2).

Such a discourse is not new. The government of Malaysia is fairly optimistic that the inclusion of the Jawi script lesson can be relevant for every Malaysian irrespective of their religions or ethnicities. Also, at the moment, prime minister Tun Mahathir, keep attempting to convince the people to believe so. However, currently, on a plethora of 
Malaysian media, although the discourse encouraging other non-Jawi scripts to learn at schools, Jawi is portrayed to receives the most special treatment. Briefly, the plan of Education Ministry to officialize the Jawi and khat subject in the coming 2020 still looks forward to figuring out the most excellent solution, which may calm down the opponents of the Jawi lesson' policy.

Notwithstanding, such an uproar does not show very overtly in Aceh. Indeed, the Jawiwritten books transliterated into Rumi are available for those who cannot read Jawi. Seemingly, this is so due to the Muslim population that counts for the hugest number in the province, making the voice of any Jawirelated policy opponents scarcely heard. However, the discontent of some people might also be a challenge in the future, which requires reasonable anticipation from the Aceh government.

\section{Conclusion}

The spread of Islam, which reached Aceh and the Malay World, did bring about the use of Jawi in almost every sector. Ever since, the writing system enjoyed its extensive usage in literary works, constitution texts, trading letters, and religious scripts. In terms of education, traditional Islamic schools (dayah) of Aceh mostly the institutions which preserve the inclusion of Jawi books in their curriculum. After the qanun 1999 echoed, other shariarelated qanuns, one of which, qanun 2008, follow in coming into effect. This qanun highly recommends the addition of new subjects in formals schools. One of the chosen additional topic is Jawi book learning.

Comparing Aceh with Malaysia, this paper underlines several positives for Aceh to consider. First, both Aceh and Malaysian Jawi education is backed up by the constitutional law. In practice, the regulation in Malaysia is translated into better implementation through the curriculum, determining teacher qualification, and teaching methodology. Second, the idea of collaborating Jawi subject with Qur'ān learning sells very well in both countries, yet at the moment, Malaysia has to consider non-muslim students for the sake of better 'market'.

Third, Jawi almost loses its grip when juxtaposed with Rumi. This phenomenon applies to Aceh and Malaysian society, including in the education sector. Particularly in Malaysia, it has to address the dissatisfaction of its opponents when it comes to being taught in Malay Language class.

Further researches on this issue are highly encouraged. Variables like teachers' innovations in teaching Jawi, current media discourse on Jawi education, and the development of the Jawi writing system in Aceh and Malaysia can be the next study topics.

\section{Acknowledgment}

I much appreciate DAAD (Deutscher Akademischer Austauschdienst) for the financial support during my MA program, and my sincere gratitude goes to Prof. Dr. Arndt Graf, Chairman of Southeast Asian Studies Department at Goethe Universiät, for the supervision.

\section{References}

Abd Jalal, A. F., Abdul Rahim, R. A., Hj. Kahal, S. M., Mansor, M. S., Ismail, A. H., Ismail, H., ... Alias, A. W. (2018). Kitab Jawi Sebagai Asas Tamadun Melayu Islam. Asian Journal of Environment, History and Heritage, 2(1). 153-169.

Abdullah, N. M. H., Siraj, S., Hussin, Z., \& Alias, N. (2010). Isu-isu kritikal penggunaan tulisan jawi dalam pelaksanaan kurikulum pendidikan Islam peringkat sekolah menengah: pandangan pakar (Doctoral dissertation, Fakulti Pendidikan, Universiti Malaya).

Adilandari, R. (2018). Pelaksanaan Program Pendidikan Diniyah dalam Upaya Peningkatan Akhlakul Karimah Pada Siswa SMPN 2 Kota Banda Aceh. 
Afif. (2014, October). KontraS sebut pelaksanaan Qanun Jinayat di Aceh melanggar HAM. Merdeka.com. Retrieved from https://www.merdeka.com/peristiwa/k ontras-sebut-pelaksanaan-qanun-jinayatdi-aceh-melanggar-ham.html. Accessed on February 23, 2020.

Ahmad, S., Othman, H., Afkari, R., Rusdi, M., \& Rahim, M. H. A. (2012). Cabaran Semasa Tulisan Jawi Sebagai Warisan Masyarakat Peradaban Bangsa Melayu. Journal of Techno Social, 4(2).

Alfian, I. (2004). Wajah Aceh dalam lintas sejarah. Pusat Dokumentasi dan Informasi Aceh.

Alfian, T. H. I. (1999). Aceh Dalam Bingkai Negara Kesatuan Republik Indonesia. Jurnal Ketahanan Nasional, 4(1999).

Ali, W., \& Kamaruddin, W. Z. (2009). Masyarakat Muslim di Negara Brunei Darussalam: kajian mengenai isu dan cabaran dalam pemikiran Islam era globalisasi. Borneo Research Journal, 3, 187-208.

Andaya, L Y. (2001). Aceh's contribution to standards of Malayness. Archipel, 611), 29-68.

Ar, Z. (2019, August 14). Education Ministry: Jawi, not khat, lesson stays, but only with parents' consent. Malay Mail. Retrieved from

https://www.malaymail.com/news/mal aysia/2019/08/14/education-ministryjawi-not-khat-lesson-stays-but-only-withparents-consent/1780678. Accessed on August 18, 2019.

Ariffin, R. M. R. (1999). Bahasa Melayu dalam warkah Melayu terpilih (Doctoral dissertation, Fakulti Bahasa dan Linguistik, Universiti Malaya).

Aziz, A. Y. A., Wan Sulung, W. M., \& Alias, N. (2017). Penaakulan Perkembangan Tulisan Jawi Mutakhir Berdasarkan Etimologi. Mahawangsa, 4(2), 187-200.

Boudersa, N. (2016). The Importance of Teachers' Training Programs and Professional Development in the Algerian Educational Context: Toward
Informed and Effective Teaching Practices. Dinamika Tulisan Arab-Jawi di Aceh. (2014, September 23). Retrieved from

http://www.jabbarsabil.com/2014/09/di namika-tulisan-arab-jawi-di-aceh.html.

Accessed on August 19, 2019.

Dinas Pendidikan Dan Kebudayaan Kota Banda Aceh (2017, October 24). Training of Trainer (TOT) Guru Diniyah Kota Banda Aceh. $\quad$ Retrieved from http://dikbud.bandaacehkota.go.id/2017 /10/24/training-of-trainer-tot-gurudiniyah-kota-banda-aceh/. Accessed on February 23, 2020.

Durie, M. (1996). Framing the Acehnese text: Language choice and discourse structures in Aceh. Oceanic linguistics, 113-137.

Fikri, M. (n.d.). Pendidikan diniyah pada sekolah umum di banda aceh (suatu tinjauan ulang).

FMT Reporters. (2019, August 7). Jawi and khat not Malaysia's identity, says non-Muslim group. FMT News. Retrieved from https://www.freemalaysiatoday.com/cat egory/nation/2019/08/07/jawi-andkhat-not-malaysias-identity-says-nonmuslim-group/. Accessed on August 19, 2019.

FMT Reporters. (2020, January 2). Jawi in Chinese schools only if $51 \%$ of parents, PTAs agree, says Teo. FMT News. Retrieved from https://www.freemalaysiatoday.com/cat egory/nation/2020/01/02/jawi-inchinese-schools-only-if-51-of-parentsptas-agree-says-teo/. Accessed on February 23, 2020.Harun, J. (2017). Kedudukan Istimewa Karya Agung Adab Ketatanegaraan Kesultanan Aceh Darussalam Dalam Sejarah Persuratan Melayu. Jurnal Melayu, 4-27

Harun, J. (2013). Mir'at Al-Tullab By Syeikh Abdul Rauf Singkel: A Preliminary Study Of Manuscripts Kept In The Special 
Collections, Leiden University Library. Malay literature, 26(2). 119-138.

IAIN Cot Kala Langsa (2012, October 15). Pelatihan Guru Madrasah. Retrieved from http://iainlangsa.ac.id/detailpost/pelati han-guru-madrasah. Accessed on February 23, 2020.

Ibrahim, M., Arifin, M., Sulaiman, N., Sufi, R., Ahmad, Z., \& Alfian, T. I. (1991). Sejarah daerah propinsi daerah istimewa Aceh. Direktorat Jenderal Kebudayaan.

Jailani (2017). Peran dan Tanggungjawab Dayah dalam Membina Akhlak Santri. At-Ta'dib, 9(2), 179-195.

Jasmi, K. A. (2010). Guru cemerlang Pendidikan Islam sekolah menengah di Malaysia: Satu kajian kes (Doctoral dissertation, Universiti Kebangsaan Malaysia).

Kantor Wilayah Kementerian Agama Provinsi Aceh. (2017, May 18). Usai Pelatihan Guru Madin, Kakanwil Buka Orientasi Kurikulum TPQ. Retrieved from https://aceh.kemenag.go.id/berita/4980 30/usai-pelatihan-guru-madin-kakanwilbuka-orientasi-kurikulum-tpq. Accessed on February 23, 2020.

Kantor Wilayah Kementerian Agama Provonsi Aceh. (n.d.). Pendidikan Diniyah dan Pondok Pesantren. Retreived from https://aceh.kemenag.go.id/artikel/2849 9/pendidikan-diniyah-dan-pondokpesantren. Accessed on February 23, 2020.

Kantor Wilayah Kementerian Agama Provinsi Aceh. (2012, July 07). Disdikpora Banda Aceh Training Guru Diniyah. Retrieved from

https://aceh.kemenag.go.id/berita/9825 8/disdikpora-banda-aceh-training-gurudiniyah. Accessed on February 23, 2020.

Kelly, A. V. (1983; 1999) The Curriculum. Theory and practice 4e, London: Paul Chapman.

Kementerian Pendidikan Malaysia. (n.d.). Panduan Pelaksanaan Kem Cemerlang Jawi.

Le Roux. P. (1998). To Be or Not to Be...: The Cultural Identity of the Jawi (Thailand).
Asian Folklore Studies, 57(2), 223-255. DOI: $10.2307 / 1178753$.

Mahmazar. (n.d.). Dinamika Aksara Arab Melayu di Aceh (Thesis proposal). Retrieved from https://www.academia.edu/8220910/DI NAMIKA AKSARA ARAB MELAYU DI ACEH. Accessed on February 23, 2020.

Majid, L. A. (2017). Methods of Teaching and Learning of Jawi Braille to Visually Impaired Students in Special Education Religious Schools. Tinta artikulasi membina ummah, 3(2), 59-67.

Kementerian Pendidikan Malaysia (2015). Kurikulum standard sekolah rendah: Dokumen standard kurikulum dan pentaksiran (draf) tahun enam.

Mamat, A. B., Kamis, R. B., \& Rashid, A. A. (2012). Student's Perceptions Towards The Teaching And Learning Of Jawi (Arabic Letter) Under J-QAF Programme: A Case Study At Selected Government Primary Schools In The District Of Hulu Selangor., presented at International Conference on Quality Of Teaching \& Learning , Terengganu, 2012.

Marzuki (2016). Diniyyah in public schools: a model of Islamic curriculum implementation in multi religious society in Banda Aceh-Indonesia. Jurnal IImiah Peuradeun, 4(1), 15-26. DOI: 10.13140/RG.2.1.2823.2721.

Marzuki (2011). Sejarah dan Perubahan Pesantren di Aceh. Millah, 11(1), 221-234.

Miszuwar, Z. (2017). Implementasi Metode Pembelajaran Teks Jawi Kitab Kuning di Dayah Latansa Zikrullah Mugan Kecamatan Montasik. Skripsi thesis, UIN Ar-Raniry Banda Aceh.

Nahar, N., Safar, J., Hehsan, A., \& Junaidi, J (2017). The Professional Competency Of Islamic Studies Teachers In Malacca, Malaysia In Jawi Teaching: A Review Study, 2nd International Conference on Law, 
Economics and Education (ICONLEE), Shah Alam, 2017.

Nasir, M. (2013). Pengembangan kurikulum muatan lokal dalam konteks pendidikan islam di madrasah. Hunafa: Jurnal Studia Islamika, 10(1), 1-18.

Nazaruddin, T., Safa'at, R., Fadli, M., \& Nurjaya, I. N. (2016). Legal Political of Aceh Sustainable Spatial Reconstruction Based on Local Wisdom of Mukim Customary Legal Community.JL Poly \& Globalization, 56, 69.

Neuendorf, K. A. (2002). The Content Analysis Guidebook. London: Sage Publications.

Novita, I. (2019). Manajemen Pembelajaran Program Diniyah Di SDIT Nurul Ishlah Banda Aceh. DAYAH: Journal of Islamic Education, 2(1), 20-35.

Pemerintah Aceh. (2013, October 02). Dayah: Sejak Sultan Hingga Sekarang. Retrieved from

https://www.acehprov.go.id/jelajah/rea d/2013/10/02/14/dayah-sejak-sultanhingga-sekarang.html. Accessed on February 23, 2020.

Phatankar, P. S. \& Jadhav, M. S. (2013). Role of teachers' in curriculum development for teacher education.

Rahim, S. N. A., \& Hamzah, R. (2016). E-Jawi: Digital Learning Tool For Jawi Character Recognition. Journal of Computing Technologies and Creative Content (JTeC), 11), 55-58.

Rusdi, A. (2016). Desain Pembelajaran Pendidikan Agama Islam Berbasis Tulisan Arab Melayu. Intizar, 22(1), 1-22.

Samad, S. A. A. (2019). Pembelajaran Arab Melayu dan Pengaruhnya Terhadap Pembentukan Karakter Siswa di Sekolah Dasar Kabupaten Pidie, Aceh. Ekspose: Jurnal Penelitian Hukum dan Pendidikan, 171), 499-513.

Sherman, R. R., \& Webb, R. B. (Eds.). (2005). Qualitative Research in Education: Focus and Methods. London: RoutledgeFalmer.

Shitiq, H. A. A. H., \& Mahmud, R. (2010, November). Using an Edutainment
Approach of a Snake and Ladder game for teaching Jawi Script. In 2010 International Conference on Education and Management Technology (pp. 228232). IEEE.

Suhid, A., Che Noh, M. A., \& Abdul Mutalib, L. (2014) j-QAF programme: an effort towards strengthening the Islamic education in Malaysia. World Journal of Islamic History and Civilization, 4 (3). pp. 82-88

Sukoyo, J. (2015, October 23). ICJR Anggap Qanun Jinayat Aceh Melanggar HAM. Berita Satu. Retrieved from https://www.beritasatu.com/nasional/31 6579/icjr-anggap-qanun-jinayat-acehmelanggar-ham. Accessed on February 23, 2020.

Sapardjaja. K. E. (2012). Qanun Aceh.

Srimulyani, E. (2013). Islamic Schooling in Aceh: Change, Reform, and Local Context. Studia Islamika, 20(3), 467-487.

Ujang, S., \& Salleh, N. M. (2018). Pelaksanaan Jawi, Al-Quran, Bahasa Arab, Fardu Ain (jQAF) dalam Program Pendidikan Khas Integrasi. Jurnal Ortopedagogia, 4(1), 5965.

Van Der Putten, J., \& Cody, M. K. (Eds.). (2009). Lost times and untold tales from the Malay world. NUS Press.Voorhoeve, P., with T. Iskandar. (1994). Catalogue of Acehnese manuscripts in the library of Leiden University and other collections outside Aceh. Translated and edited by Mark Durie. Leiden: Leiden University Library (Legatum Warnerianum).

Yusoff, M. A. (2005). Perkembangan tulisan jawi dan aplikasinya dalam masyarakat islam di malaysia. Jurnal Usuluddin, 21, 23-38.

Zain, S. M. (2010). Hikayat Raja Pasai: sebuah sorotan tarikh penulisannya, kemasukan Islam di Pascabima (Alam Melayu) dan pelbagai ilmu di dalamnya. Jurnal Filologi Melayu, 17, 1-37. 